\title{
Exploration of the level of knowledge on organic and food security of adolescent, young and adult students of a public school in Palmas-TO
}

\author{
Katiane Machado Gomes Barbosa ${ }^{1}$, Gustavo Cunha de Araújo ${ }^{2}$ e \\ Deyla Paula de Oliveira ${ }^{3}$
}

1 Graduada em Ciências Biológicas e em Pedagogia pela Universidade Federal do Tocantins. Professora da rede municipal de ensino do Tocantins, Brasil. E-mail: katianejemachado@gmail.com

2 Doutorando em Educação pela UNESP. Mestre em Educação pela UFMT. Graduado emEducação Artística (Artes Visuais) pela UFU. Professor da Universidade Federal do Tocantins, Brasil. E-mail: gustavocaraujo@yahoo.com.br

3 Pós-Doutora em Biologia Molecular. Mestre e Doutora em Genética, Conservação e Biologia Evolutiva. Professora da Universidade Estadual do Tocantins, Brasil. E-mail: deylaoliver@gmail.com

ABSTRACT: The study analyzes the knowledge and consumption of organic foods and the understanding on the concept of food security of 60 regular elementary school students and 46 students of the youth and adult education (YAE) from a public school in Palmas, Tocantins State. From a qualitative-quantitative and exploratory approach, this study used as a methodological data collection instrument a semi-structured questionnaire with five questions, applied to regular elementary and high school students. The answers given to the questions were categorized in percentages and analyzed by the techniques of statistical and content analyses. Among other results, the research verified the lack of knowledge of these students regarding this subject. Given this, school must develop strategies and effective practical actions, not just theoretical ones, able to encourage the adherence of healthier food choices to students. It is concluded that it is essential to emphasize the theme of healthy eating in science teaching.

Keywords: Food education, Science, Education.

Investigação do nível de conhecimento sobre orgânicos e segurança alimentar de estudantes adolescentes, jovens e adultos de uma escola pública de Palmas-TO

RESUMO: $O$ estudo analisa o consumo e o conhecimento de alimentos orgânicos e a compreensão do conceito de segurança alimentar de 60 estudantes do ensino fundamental regular e 46 estudantes da educação de jovens e adultos (EJA), de uma escola pública em Palmas, Estado do Tocantins. De abordagem quali-quantitativa e de natureza exploratória, este estudo utilizou como instrumento metodológico de coleta de dados um questionário semiestruturado de cinco questões, aplicado a estudantes do ensino fundamental regular e da EJA. As respostas dadas às questões foram categorizadas em porcentagens e analisadas pela técnica de análise estatística e pela de análise de conteúdo. Dentre outros resultados, a pesquisa constatou a falta de conhecimento desses estudantes com relação ao tema do estudo. Diante disso, a escola deve elaborar estratégias e ações práticas, e não apenas teóricas, que incentive a adesão de escolhas alimentares mais saudáveis pelos estudantes. Conclui-se que é de fundamental importância enfatizar o tema alimentação saudável no ensino de ciências.

Palavras-chave: Educação Alimentar, Ciências, Educação.

\section{INTRODUCTION}

Modern organic agriculture emerged in the 1960 s as producers and consumers started to recognize that the use of chemical inputs in food production could cause serious health problems for the population and the environment. 
In Brazil, the organic production system is regulated by the Federal Law n. 10.831 , from December 23, 2003, which contains disciplinary rules for the production, typing, processing, packaging, distribution, identification and certification of organic product quality, of animal or vegetable origin.

Organic agriculture is defined as an integrated production system which promotes and strengthens healthy agro-systems, which includes biodiversity, biological cycles and soil biological activity. In this system, practices of the use of low inputs quantity are adopted and take into account the regional conditions required for local adaptations to the production (HERNÁNDEZ, 2000).

Regarding the nutritional aspects, in some studies with organic foods, the reduction of nitrate content and a high vitamin C content were observed (BORGUINI; TORRES, 2006). Therefore, organic agriculture is an option for the production safe and nutritionally rich food.

In this reasoning, the interest in consumption of food with higher nutritional value and lower content of contaminants, besides the search for healthier life habits, has contributed to boost the organic food consumption in society (SCIALABBA, 2005).

Knowledge concerning how food is produced, its origin, care at the time of purchase and its proper preparation and preservation of the nutritional characteristics and health and hygiene conditions becomes essential and in line with the term food security (FAO/WHO, 1997).

When reflecting on food education, Bonatto (2013) states that good nutrition enables the individual to have better cognitive, affective and psychomotor development. In fact, in addition to preventing dis- eases in the future, such as diabetes, obesity, among others, healthy eating may favor better school performance in children and adolescents. In addition to that, policies which promote healthy eating (PAS) recognize the school as a space that can contribute to adopt healthy habits throughout the school community (CAMOZZI et al., 2015).

However, the school basic education curriculum $^{1}$ and that of the youth and adult education (YAE) should address subjects related to food and nutrition, with the aim of stimulating healthy eating habits in children, adolescents, young people and adults, as the Resolution CNE/CEB n. 2, of January 30 (BRASIL, 2012), in its article 10:

As a result of specific legislation, these are mandatory [...]. Item II - Transversal and integrated treatment, permeating the whole curriculum, within the scope of other curricular components: food and nutritional education (BRASIL, 2012, p. 03).

Regarding the youth and adults education, it is worth mentioning that over the last years it has been an important modality of education that seeks to tackle social inequalities and school exclusion, consisting the most important mean of inclusion for these people who could not initiate or continue their studies in basic education. The Law n. ${ }^{\circ}$ 9.394/96 (BRASIL, 2013) and the National Curricular Guidelines (BRASIL, 1997) will provide legal support for the youth and adult education in Brazil, by providing the YAE to those who have had their studies denied or interrupted for sev-

\footnotetext{
${ }^{1}$ The curriculum is seen as organization, selection, realization, institutionalization and evaluation of knowledge relevant and necessary for the education and training of the individual, taking into account ethical, political, aesthetic and cultural issues (MACEDO, 2013).
} 
eral reasons and which must be offered at free educational institutions.

Issues such as what has been addressed in the curriculum of regular education and YAE, especially regarding security and food education, make it interesting to study that in the educational field. Specifically for the $Y A E$, the guarantee and right to education of young people and adults is a constant prerogative that cannot be left aside by the State nor by the school and university. Therefore, it is understood that education is indispensable for the exercise of citizenship and for the cultural, political and social formation of the individual (PAIVA, 2007, $p$. 77).

Under this perspective, Machado (2016) questions the conception of education desired. Thus, the author highlights the need to reinforce the commitment, as educators, to understand education as a human, political and social practice, having in it the democratic access to building new knowledge and more active participation of the student in decision making in Brazilian society.

According to Santos and Amorim (2016), Brazilian education in recent years has undergone changes and advances in reflections on the school curriculum, with a traditional tendency still present in scholar institutions which aim, among other factors, the knowledge transmission, but not always taking into account the real learning needs of the students.

In this sense, it is necessary to think of a curriculum that addresses relevant issues to the student's education, such as food security and education in order to have healthier eating habits. In this line of reasoning, education needs to get people out of the naive transitivity, of the common sense in which the majority of society still lives in the country and requires the consolidation of true critical awareness, a broad society and world view, avoiding the massification of the individual, with the implantation and development of a new active, dialogical and participative method in the process of educating (SANTOS; AMORIM, 2016, p. 124).

Based on these considerations, it is important to emphasize that food education is still a territory scarcely mapped by Brazilian educational research, especially regarding the knowledge of adolescents, youth and adults in relation to organic food and food security. It is important to emphasize that Bonatto (2013) study on food education reaffirms the importance of discussing the subject not only in the elementary school and high school, but also in the young and adult education, which demonstrates the relevance to produce and socialize knowledge regarding the object of study emphasized in this research. In other words, the theme of food education should be addressed at school, from the beginning of schooling until the adulthood, including those who returned to school to continue and complete their studies, in this case, the youth and adults education.

From an exploratory, qualitativequantitative research perspective, the article aimed to investigate the consumption and knowledge on organic food and the understanding of the concept of food security for students of the $9^{\text {th }}$ grade regular school and students of the youth and adult education (YAE) of the Jorge Amado Municipal School, municipality of Palmas, State of Tocantins, Brazil. 


\section{MATERIAL AND METHODS}

This quali-quantitative research is characterized as exploratory research (TRIVIÑOS, 1987, p. 109), because it "allows the researcher to increase his experience around a certain problem", since it "is a fundamental practice for the professional development of the teacher" (LUDKE, 2001, p. 25). Following this perspective, it is understood that research should not be dissociated from pedagogical theory and practice, since school is considered an important space for the process of knowledge production.

The researcher starts from a hypothesis and deepens his study within the limits of a specific reality [...] the researcher plans an exploratory study to find the necessary elements that allow him, in contact with a certain population, to obtain the results he desires. An exploratory study, on the other hand, may serve to raise possible research problems (TRIVIÑOS, 1987, p. 109).

Although some young people and adults have a better understanding of what organic foods and food security are in Science class, because returning to school to complete their studies brings significant baggage of experience and knowledge acquired over the course of life, it is hypothesized that in the researched school, not all the students of the Regular Elementary School and the YAE have knowledge on this subject.

In order to obtain the data, a semistructured questionnaire was used, which, according to Barros and Lehfeld (1990), is a procedure that allows obtaining information directly and systematically. The questionnaire was composed of five simple and objective questions, some of them with a request for the response justification, handed out in a collective manner inside the classroom, with the help of the teacher and with the prior consent of the school staff, in addition to having a voluntary character.

The studied population was composed of regular primary school students and students of the youth and adult education (YAE) of the Jorge Amado Municipal School, located in the municipality of Palmas, State of Tocantins. Regarding the socioeconomic and cultural level, it was detected that most of the families of the regular education and of the YAE students have economic difficulties, little specialization and schooling. As for the YAE night shift, most of the students at this period are workers, of lower middle class, who work all day long in the formal or informal labor market, presenting great age/grade distortion and learning difficulties due to the long time they have been out of school.

The sample consisted of 60 (sixty) students aged 13 to 15 years old, from three $9^{\text {th }}$ grade classes of regular primary education, of which 20 (twenty) students from each class were interviewed, and from 46 students with 15 to more than 45 years old of 4 (four) classes $\left(6^{\text {th }}, 7^{\text {th }}, 8^{\text {th }}\right.$ and $9^{\text {th }}$ grades) of the YAE. In the $6^{\text {th }}$ grade of the YAE, 12 students were interviewed $(n=18$, $66.6 \%)$; in the $7^{\text {th }}$ grade, 13 students $(n=17$, $76.4 \%)$; in the $8^{\text {th }}$ grade, 11 students $(n=17$, $73.3 \%)$ and in the $9^{\text {th }}$ grade, 10 students $(\mathrm{n}=$ $17,66.6 \%)$.

The School facilitated all the steps necessary to apply the questionnaire that was applied in June 2016. The students answered the questionnaire during the science class. Thus, this study sought to an- 
swer the following problem: what is the knowledge on organic food and the understanding of the concept of food security of students of the $9^{\text {th }}$ grade regular school and those of the YAE of the Jorge Amado Municipal School, municipality of Palmas, State Of Tocantins, Brazil?

The study comprised three moments: i. initial contact, when it was sought to know the school as a field of research; ii. application of the questionnaire, when the closest contact with the students was established; iii. tabulation and qualitative and quantitative analysis of the data collected. The answers $^{2}$ given to the questions were categorized in percentages and analyzed by the techniques of statistical and content analyses $^{3}$.

\section{RESULTS AND DISCUSSION}

According to the Political Pedagogical Project (PPP) of the researched school, there is a concern about the security and food education of students and staff of this institution, since one of the objectives described in the PPP is to elaborate a menu that addresses the school staff's and students' interests. It is important to mention that the menu is checked by nutritionists, before the preparation and consumption. After that analysis and not identifying any problems on the menu, the food is prepared to be served weekly to the students and school staff.

\footnotetext{
${ }^{2}$ The most meaningful and often answers from the students' report were selected.

${ }^{3}$ According to Bardin (2009) this technique may be applied to different discourses and has the objective of obtaining qualitative and quantitative information, based on data systematization, that may allow inferences of knowledge on the analyzed messages.
}

Our school needs to have four different menus, because it works during the three shifts. Furthermore, we have the More Education Program, in which the students spend full time in it [...] for them [students] a menu with lunch and dessert is prepared (POLITICAL PEDAGOGICAL PROJECT, 2017, p. 72).

An interesting aspect pointed out at the school PPP is that it is avoided to store food in tanks, in order to better preserve what will be prepared in the meals during the whole week. Besides, this institution maintains an agreement with the School Feeding National Program - PNAE ${ }^{4}$.

However, the analyses of the answers about the level of the knowledge of students at the $9^{\text {th }}$ grade of Regular Elementary Teaching of the Jorge Amado Municipal School in relation to organic foods showed that $40 \%(n=24)$ of the students knew the subject; $43 \%(n=26)$ knew little and $17 \%$ $(n=10)$ said they did not know. From the YAE students, $63 \%$ ( $n=29$ ) know the subject; $24 \%(n=11)$ knew little and $13 \%$ ( $n=$ $6)$ said they did not know (Table 1 ). The data of the YAE students is similar to that found in a study by Cavallet et al. (2013), in which $60 \%$ of the interviewees knew what organic food was and $49.5 \%$ had already consumed it. From the data of the present study, it can be concluded that the subject is better known by the YAE students. However, in contrast, Lucena et al. (2015), in a research with the students and employees of a Primary School located in the countryside of Barbalha, State of Ceará, found that $60 \%$ of the students and $65 \%$ of the inter-

\footnotetext{
${ }^{4}$ Program of the Federal Government that was first implemented in 1955 and aims to contribute to the development, growth, learning and school performance of students of basic education and YAE in Brazilian schools, based on healthy eating habits.
} 
viewed employees did not have knowledge about the subject. However, it was found that about $20 \%$ of the students had the habit of ingesting natural food grown in their own homes.

Table 1. Percentage of the interviewed students' answers on the following question: Have you heard about organic or pesticide-free foods?

\begin{tabular}{l|c|c|c|c}
\hline \multirow{2}{*}{\multicolumn{1}{c|}{ Answers }} & \multicolumn{2}{c|}{ Regular students } & \multicolumn{2}{c}{ YAE students } \\
\cline { 2 - 5 } & Total & $\%$ & Total & $\%$ \\
\hline Yes & 24 & 40 & 29 & 63 \\
\hline Now & 10 & 17 & 6 & 13 \\
\hline Very little & 26 & 43 & 11 & 24 \\
\hline TOTAL & 60 & 100 & 46 & 100 \\
\hline
\end{tabular}

Source: Prepared by the authors.

Silva et al. (2013) identified how the health and dietary methods of 48 YAE students in the $3^{\text {rd }}$ and $4^{\text {th }}, 6^{\text {th }}$ and $8^{\text {th }}$ grades at the Antônio Aurélio Teixeira de Carvalho Municipal Elementary School, municipality of Lucena, State of Paraíba were. The authors found that although the YAE students are subjects rich in knowledge that has been built throughout their existence and know about healthy eating, they do not make use of healthy foods. These students also pointed out that the financial conditions are obstacles to a good and healthy diet. Still according to the same authors, one of this school student's parents owns an organic vegetable garden that does not use pesticides in the plantation, and uses a natural insect repellent, the plant "Nim". Taking this example into consideration, the policy of promoting school feeding could enable home gardening activities, including good practices in food handling and monitoring of nutritional status of schoolchildren (CAMOZZI et al., 2015). Thus, the rescue of land cultivation, the reflection on the importance of the consumption of organic foods and the approach of this theme in the classroom can stimulate healthier eating habits and promote the nutritional education the school community.

From the perception of parents and educators, Oliveira (2017) described the impact on feeding associated with the experience of children in food production in school gardens. According to the authors, the experience had an impact on the children and families involved in such activities, providing reflection on the act of eating and on food, through the knowledge acquired through direct contact with the cultivation of these foods.

According to Lucena et al. (2015), an organic garden contributes to the strengthening of environmental education and ecological agriculture. In this sense, the authors reported the implementation of an organic vegetable garden at the Sebastião Elementary School, located in the Barbalha countryside, State of Ceará. The school garden project allowed the awakening of students' social values, such as participation, interpersonal relationship, sense of responsibility and awareness of issues related to the environment.

In this regard, the present study did not verify the presence of an organic garden at the Jorge Amado Municipal School, nor was this term identified the PPP, which makes it clear that even if the school worries about healthier eating habits, there is no project in development or that will be developed in the future, referring to the presence of the organic garden in this school space.

As $43 \%$ of the $9^{\text {th }}$ grade students know little about the subject, it is recommended that there be better awareness of this particular audience on organic agriculture, as well as its importance and benefits to health and the environment. It is important 
to highlight that the intensive use of pesticides has generated several problems, such as contamination of food, soil, water, animals; the intoxication of farmers; resistance of pathogens, pests and invasive plants to certain pesticides; biological imbalance and the reduction of biodiversity (LUCENA et al., 2015). It is also worth mentioning the need for more studies like this one, in order to analyze the insertion of organic foods and their acceptability in school feeding the Jorge Amado Municipal School.

When this panorama comes to thought and with the aim to improve the quality of food for students in the Paraná State's school system, the Law $\mathrm{n}^{\circ} 16.751$ was instituted in 2010, that establishes that school meals should consist of organic foods (MAZUR et al., 2013), an idea that can be adopted in schools of the municipal and state systems of the Tocantins State.

For students in the $9^{\text {th }}$ grade of regular Elementary School who have mentioned having knowledge about the subject, organic food refers to fruits such as mangoes, apples, watermelons, pears and grapes. For the YAE students, organic food refers to natural food, plants or food without pesticides such as vegetables and fruits. However, it is worth mentioning the speech of two YAE students, where they mention about the difficulty in finding free-pesticide food and the needed use of pesticides to increase food production for humanity:

"Yes, but in our day-to-day it is very difficult to feed without pesticides. In the past it was much easier to find food without pesticides" $\left(B, 7^{\text {th }}\right.$ grade, $\left.Y A E\right)$.

"Yes, everything we eat has pesticides, because without them there is no food for everybody" (MLS, $7^{\text {th }}$ grade, YAE).
The consumer market for organic fruits and vegetables has been increasing significantly. However, vegetables are the most commercialized organic products in Brazil (ORMOND et al., 2002). In a study carried out by Andrade and Bertoldi (2012) in the city of Belo Horizonte, State of Minas Gerais, fruits and vegetables were the most consumed organic foods in 2011.

Regarding the knowledge about food security of students in the $9^{\text {th }}$ grade students of the regular Elementary School, $40 \%$ ( $n=$ 24) of the students said they knew the subject, $28 \%(n=17)$ knew little and for $32 \%$ ( $n$ $=19$ ) it was totally unknown. For the YAE students, $54 \%$ ( $n=25$ ) of the students said they knew the subject, $26 \%(n=12)$ knew little and $20 \%(n=9)$ were totally unaware (Table 2). Although $40 \%$ of the regular elementary school students and $54 \%$ of those in the YAE have responded that they have heard about food security, we recommend greater investments in educational approaches aimed at better understanding what would actually be food security and healthy eating, since it started to integrate proposals for public policies in the health area, emphasizing the guarantee of adequate food for the population, since the 1990s (SILVA et al., 2009).

Table 2. Percentage of the interviewed students' answers, on the following question: Have you heard about food security?

\begin{tabular}{l|c|c|c|c}
\hline \multirow{2}{*}{\multicolumn{1}{c|}{ Answers }} & \multicolumn{2}{c|}{ Regular students } & \multicolumn{2}{c}{ YAE students } \\
\cline { 2 - 5 } & Total & $\%$ & Total & $\%$ \\
\hline Yes & 24 & 40 & 25 & 54 \\
\hline No & 19 & 32 & 9 & 20 \\
\hline Very little & 17 & 28 & 12 & 26 \\
\hline TOTAL & 60 & 100 & 46 & 100 \\
\hline
\end{tabular}

Source: Prepared by the authors.

In agreement with the main (PRINCIPLES AND GUIDELINES FOR A FOOD AND NUTRI- 
TION SECURITY POLICY, 2004), the food and nutritional security is defined in Brazil as:

Realization of the right of all to the regular and permanent access to sufficient quality food without compromising access to other essential needs, based on health-promoting food practices that respect cultural diversity and which are socially, economically and environmentally sustainable development (PRINCIPLES AND GUIDELINES FOR A FOOD AND NUTRITION SECURITY POLICY, 2004, p. 04) .

In other words, food security is everyone's right, but the particularities and characteristics of each region of the country must be respected in terms of access, consumption and good practices of healthy food.

It was also found in this study that $5 \%$ $(n=3)$ of the $9^{\text {th }}$ graders believe that poor nutrition does not interfere with people's lives, $3 \%(n=2)$ believe in low interference and $92 \%(n=55)$ think it interferes (Table 3). Eighty-five percent $(n=39)$ of the YAE students reported that poor eating interferes with people's lives, $6 \%(n=3)$, believe in low interference, and $9 \%(n=4)$ thought it did not interfere (Table 3).

Table 3. Percentage of the interviewed students' answers on the following question: Do you think that poor nutrition can interfere with people's health?

\begin{tabular}{l|c|c|c|c}
\hline \multirow{2}{*}{\multicolumn{1}{c|}{ Answers }} & \multicolumn{2}{|c|}{ Regular students } & \multicolumn{2}{c}{ YAE students } \\
\cline { 2 - 5 } & Total & $\%$ & Total & $\%$ \\
\hline Yes & 55 & 92 & 39 & 85 \\
\hline No & 3 & 5 & 4 & 9 \\
\hline Very little & 2 & 3 & 3 & 6 \\
\hline TOTAL & 60 & 100 & & 100 \\
\hline
\end{tabular}

Source: Prepared by the authors.

In dialogue with this analysis, it was possible to identify that for more than $80 \%$ of the students ${ }^{5}$ of the two modalities, there is a certain concern with the food. This situation was evident in the discourse of six students:

"Food is life" (MVS, regular $9^{\text {th }}$ grade).

"Without healthy eating, you cannot have a good quality of life" (SEGS, regular $9^{\text {th }}$ grade).

"To live we need good nutrition" (TBS, regular $9^{\text {th }}$ grade).

"If you do not have quality and healthy eating you cannot be a healthy person" (YMS, regu$\operatorname{lar} 9^{\text {th }}$ grade).

"Yes, it can, because a person who does not eat properly can have health problems" (B, 7 th grade, $Y A E)$.

"Because if people eat badly, it's easier for them to get sick" (DMS, $9^{\text {th }}$ grade, YAE).

In order for food to be considered healthy, varietal, balanced, accessible, safe and attending to the nutritional, such as vitamins, proteins, minerals and fibers, demands necessary for human health should be considered (BRASIL, 2009). However, factors such as the lack of knowledge about these questions, their causes and possible health effects are factors that can negatively influence a person's eating habits (AGOSTINHO et al., 2012). It is known that healthy foods, besides avoiding some illnesses, such as blood pressure alterations (high blood pressure), diabetes, obesity, cardiovascular disease, etc., bring other benefits such as, for example, the supply of nutrients essential for the health mainte-

\footnotetext{
${ }^{5}$ This study follows guidelines and ethical principles for scientific research. Therefore, the names of the students are anonymous.
} 
nance of the body and an increased willingness to perform various daily tasks, a fact that can be associated with the report of six students in this research.

For $37 \%(n=22)$ of the students of the $9^{\text {th }}$ grade of regular elementary school, the health technical team should be responsible for teaching the topic of healthy eating in the school community. For $30 \%(n=18)$, the family should be responsible for that and $33 \%(n=20)$ of these students believe that the school should discuss about this theme during classes. For $41 \%(n=19)$ of the $Y A E$ students, the health technical team should be responsible for inserting the theme of healthy eating into the school community, and $46 \%(n=21)$ think that it should be the family's responsibility and $13 \%(n=6)$, believe that this obligation should be of the school (Table 4).

Table 4. Percentual das respostas dos alunos entrevistados, sobre a seguinte questão: Em sua opinião quem deveria ser responsável por ensinar sobre alimentação saudável?

\begin{tabular}{l|c|c|c|c}
\hline \multirow{2}{*}{ Answers } & \multicolumn{2}{|c|}{ Regular students } & \multicolumn{2}{c}{ YAE students } \\
\cline { 2 - 5 } & Total & $\%$ & Total & $\%$ \\
\hline School & 20 & 33 & 6 & 13 \\
\hline Family & 18 & 30 & 21 & 46 \\
\hline Technical team & 22 & 37 & 19 & 41 \\
\hline TOTAL & 60 & 100 & 46 & 100 \\
\hline
\end{tabular}

Source: Prepared by the authors.

For Aquilla (2011), in addition to the technical health team, the family plays an important role in the transmission of knowledge on food, as it is the parents' daily task to show balanced and adequate food and encourage healthy eating for their children.

In contribution to this reflection, Motta and Teixeira (2012) thus position themselves:

We defend the thesis that food issues must be addressed from their multiple dimensions and assume the school as a strategic space not only to foster the discussions necessary to prevent and control childhood diseases (diabetes, hypertension, obesity), But also to contribute to the critical understanding of the implications of food consumption cultures for the man-environment relationship (MOTTA; TEIXEIRA, 2012, p. 366).

Bezerra et al. (2015) evaluated the knowledge and approach in healthy eating of teachers from urban municipal public schools in Montes Claros, State of Minas Gerais. The interviewed teachers mentioned that they work on the subject especially through research on books, magazines and newspapers, dialogues and classroom activities, and they also use traditional methods such as lectures. The authors concluded that the methodologies and didactic resources adopted for the teaching of healthy food in these schools are still scarce and that teachers' knowledge about the subject is moderate, indicating that they should receive specific training on it. The study also mentions that according to teachers, some family members negatively influence students' eating habits. Thus, for these teachers, the school and the family work in opposite directions, that is, while the school indicates the ideal of healthy eating, the reality of the student is different. Therefore, activities that promote healthy eating should be targeted to the entire school community, including students, teachers, and parents.

Accioly (2009) reinforces that educators, parents and the entire community play an important role in building healthy lifestyles. According to Almeida and locca (2012), the school has importance in the construction of healthy habits in the life of the students, considering that an inappropriate diet can 
also cause losses in the learning process, which can influence the teaching and learning process.

Therefore, according to these authors' position, the responsibility for teaching and encouraging healthy eating should not only fall to one actor or another, but it should be responsibility of the whole family, school community and health technical team, as National Curricular Guidelines suggests that there should be an integration of health professionals and education, family, students and community members, in the effort to incorporate the principles of health promotion to provide a healthy school environment with the insertion of practices of respect for individual and collective wellbeing (BRASIL, 1997).

With regard to the contribution of Science classes to the knowledge on healthy food and food security, $25 \% \quad(n=15)$ of the students in the $9^{\text {th }}$ grade of regular elementary education and $9 \%(n=4)$ of the YAE students stated that the school subject did not contribute to the knowledge on the theme (Table 5). For $32 \%(n=19)$ of the students in the $9^{\text {th }}$ grade of regular elementary education and $19 \%(n=9)$ of the YAE students (Table 5) considered that the subject had little contribution, which was evident in one of the statements of a $9^{\text {th }}$ grade regular student:

"In Science classes you learn more about plants and the human body, and never food" (RSC, regular $9^{\text {th }}$ grade).

For $43 \%(n=26)$ of students in the $9^{\text {th }}$ grade of regular elementary education, Science classes contributed to knowledge on organic food and food security. However, for $72 \%(n=33)$ of the YAE students, the sub- ject contributes to acquire such knowledge (Table 5). In this regard, some students interviewed justified their answers:

\footnotetext{
"Yes, because I am eating better, eating more fruits and vegetables" (WPC, regular $9^{\text {th }}$ grade).

"Science has contributed because a good eating habits change the life" ( $C, 9^{\text {th }}$ grade, YAE).

"We are taught food functions and which is better for our health" (ZFC, $9^{\text {th }}$ grade, YAE).
}

This data is in accordance to Cunha et al. (2010), the approach to health, food security and nutrition issues, taught from the 6th to the 9th year of elementary education, is the responsibility of the science teaching. To complement the didactic textbook of this discipline, other strategies can be used, such as visits to vegetable gardens and encouragement of home cultivation.

Camozzi et al. (2015) analyzed the perception and actions in the health promotion policy carried out by actors of the school community such as director, coordinator, teacher, school feeding handler and representative of school staffs from six elementary schools in a Brazilian capital. The authors emphasized that the activities promoting healthy eating in this school restrict the specific contents addressed by the teachers in the classroom space and in some school subjects such as Sciences, Physical Education and Geography and to modifications made in the school menu in order to increase the acceptance of the students. 
Tabela 5. Percentage of the interviewed students' answers on the following question: Has Science teaching contributed to their knowledge about healthy eating and food security?

\begin{tabular}{l|c|c|c|c}
\hline \multirow{2}{*}{ Answers } & \multicolumn{2}{c|}{ Regular students } & \multicolumn{2}{c}{ YAE students } \\
\cline { 2 - 5 } & Total & $\%$ & Total & $\%$ \\
\hline Yes & 26 & 43 & 33 & 72 \\
\hline No & 15 & 25 & 4 & 9 \\
\hline Very little & 19 & 32 & 9 & 19 \\
\hline TOTAL & 60 & 100 & 46 & 100 \\
\hline
\end{tabular}

Source: Prepared by the authors.

On the other hand, Santos (2005) argues for the inclusion of these themes in the School's, with the aim of fostering a critical debate of the topic throughout the school community and not just a mere inclusion of content provided in books. According to this reasoning, Veiga $(1995$, p. 33) states that "school is the place of conception, realization and evaluation of its educational project, since it needs to organize its pedagogical work based on its students."

In this sense, it is understood that a greater insertion of subjects related to the feeding in the schools is necessary, since they are subjects of paramount importance for the students and for the school community as a whole. Indeed, "the curriculum cannot be separated from the social context, since it is historically situated and culturally determined" (VEIGA, 1995, p. 27).

So, as Accioly (2009) states, promoting pedagogical discussions about healthy eating and food security in classrooms should be seen as a process to be developed in an interdisciplinary and intersectoral way. Therefore, it should not be a practice exclusively of the science and biology teaching, but it should encompass other disciplines of the school curriculum. The mentioned theme can be approached in disciplines like art, with the use of the dramatization on the subject; in the disciplines of geography and history, based on the economic and cultural role of food; in the Portuguese language through the stimulation of textual production related to food; and in physical education, the performance of food for the maintenance of body health could be emphasized.

In addition, these data reinforce the thesis that new information and communication technologies can also allow the dissemination of information related to healthy eating and alert society to the dangers of eating industrialized foods, thus encouraging the adoption of healthier eating habits.

\section{CONCLUSION}

In the present study ${ }^{6}$, it was evident that the theme of organic food and food security are still little discussed, divulged and inserted in the school context. In this sense, it is understood that the school must develop strategies and effective actions in its that encourage and promote the adherence of healthy food choices by students.

Organic foods are presented as a viable and healthy alternative to the diet of society. However, it is emphasized that promoting health and adopting healthy eating habits is an educational process that accompanies the individual's life from birth to adulthood. In this perspective, the school, as a space for the production of knowledge, presents itself as an important incentive for a healthier diet for the school community.

In this sense, the discipline of science in elementary school is a relevant space for the production and socialization of knowledge on these subjects in classrooms,

${ }^{6}$ ACKNOWLEDGMENT. We thank the Course of Biology $\mathrm{EaD}$ of the Federal University of Tocantins, Brazil; the interviewed students and the entire team of the Jorge Amado Municipal School, in Palmas, Tocantins State. 
since it allows to work on these subjects so that students can develop a critical awareness about their eating habits, taking into account the knowledge on their own habits acquired at home and/or outside the school environment, that is, it offers opportunities for the student to understand concepts and interpret actions and phenomena based on what is observed and experienced in their day to day.

Educating to eat well and consciously should be a goal to be adopted by the schools and it is hoped that they can, in fact, be encouraging healthy and balanced nutrition throughout the school communities, as well as contributing to the promotion of student health.

The diversity of students not only in regular education, but also in the YAE makes this modality of education have a more flexible pedagogical and curricular model to effectively meet the learning needs of the young person and the adult. Such flexibility can be expressed in "combinations of face-to-face and non-face-to-face teaching in a way attuned to the subjects of everyday life of the students, so that they can become elements that generate a pertinent curriculum" (BRASIL, 2000, p. 61). Thus, it is worth mentioning that the answers reported by the YAE students show that they have greater knowledge about the consumption and about organic foods and a better understanding on food security than the students of the $9^{\text {th }}$ grade regular elementary school, because they bring to school experiences and knowledge that have been built throughout their lives.

Although the researched school worries about offering a healthier food menu to the students, according to the analyzed PPP of this institution, the analyses made from the reports of the students allowed to see that not all of the students involved (three $9^{\text {th }}$ grade classes of the regular Elementary School and four YAE classes) consume and are knowledgeable about organic food and food security. Thus, it is recommended that there be better awareness to this public about organic farming, as well as its importance and benefits to health and the environment, and also healthier eating habits.

In this sense, it can be affirmed that curricular proposals that take into account the learners' learning needs, their knowledge and experiences, having students as protagonists, seek to promote improvements in the quality of education that is truly wanted and sought every day. In fact, issues related to healthy food and food security must be present in the regular elementary school curriculum and in the youth and adult education.

This study reaffirms, from an exploratory and quali-quantitative approach carried out and analyzed in the school context of Tocantins State, Brazil, the importance of discussing this topic in the school, which can serve as a starting point to continue the academic debate on food education with children, young people and adults in educational research. In fact, we hope to contribute so that new research on this theme can be produced in the academic community.

\section{REFERENCES}

ACCIOLY, E. A escola como promotora da alimentação saudável. Ciência em Tela, Rio de Janeiro, v. 2, n. 2, p. 1-9, 2009.

ALMEIDA, A. L; IOCCA, A. S. Hábitos alimentares na educação infantil. Revista Eventos Pedagógicos, v. 3, n. 2, p. 31-41, mai./jul. p. 
1-11, 2012.

ANDRADE, L.; BERTOLDI, M. Atitudes e motivações em relação ao consumo de alimentos orgânicos em Belo Horizonte-MG. Food Technology, p. 31-40, 2012.

AGOSTINHO, L. C. L. et al. (2012). A química dos alimentos no processo de ensinoaprendizagem na Educação de Jovens e Adultos - EJA. Revista Lugares de Educação, Bananeiras, v. 2, n. 1, jan./jun. p. 31-46, 2012.

AQUILLA, R. A educação alimentar e nutricional no espaço escolar: saber, sabor e saúde. 97f. Dissertação (Mestrado em Educação nas Ciências) - Universidade Regional do Noroeste do Estado do Rio Grande do Sul, Rio Grande do Sul, 2011.

BARDIN, L. Análise de conteúdo. Lisboa, Portugal: Edições 70, 2009.

BARROS, A. J.; LEHFELD, N. A. S. Projeto de Pesquisa: propostas metodológicas. Rio de Janeiro: Vozes, 1990.

BRASIL. Lei n. 9.394/96. Estabelece as diretrizes e bases da educação nacional. 8. ed. Brasília, DF: Câmara dos Deputados/Edições Câmara, 2013.

BRASIL. Resolução n. $\mathbf{2}$ de $\mathbf{3 0}$ de Janeiro de 2012. Define Diretrizes Curriculares Nacionais para o Ensino Médio. Brasília: MEC, 2012.

BRASIL. Alimentação saudável e sustentável. Eliane Said Dutra et al. Brasília. Universidade Brasília/MEC, 2009.

BRASIL. Lei Federal $n=10.831$ de dezembro de 2003. Brasília: Ministério da Agricultura, Pecuária e do Abastecimento, 2003.

BRASIL. Parecer CNE/CEB n. 11 de maio de 2000. Brasília: MEC, 2000.

BRASIL. Parâmetros Curriculares Nacionais: Segmento Arte. Brasília: MEC, 1997.

BEZERRA, K. F. et al. Conhecimento e abordagem sobre alimentação saudável por professores do ensino fundamental. Demetra,
Rio de Janeiro, v. 10, n. 1, p. 119-131, 2015. BONATTO, A. A. Comportamento alimentar dos estudantes da EJA em São Leopoldo (RS). Portal Educação, 2013. Disponível em: <https://www. portaleducacao.com.br/nutr icao/artigos/47275/comportamento-alimen tar-dos-estudantes-do-eja-em-sao-leopoldo -rs>. Acesso em: 27 jan. 2017.

BORGUINI, R. G.; TORRES, E. A. F. T. Organic Food: Nutritional Quality and Food Security. Revista Segurança Alimentar e Nutricional, Campinas, v. 13, n. 2, p. 64-75, 2006.

CAMOZZI, A. B. Q. et al. Healthy eating promotion at school: reality or an utopy? Cadernos Saúde Coletiva, Rio de Janeiro, v. 23, n. 1, p. 32-37, 2015.

CAVALLET, L. E. et al. Conhecimento da população sobre produto orgânico na região litorânea do Paraná. Revista Brasileira de Agroecologia, Rio de Janeiro, v. 8, n. 2, p. 62-74, 2013.

CUNHA, E. et al. Organic food and educational actions in schools: diagnosis for health and nutrition education. Ciência \& Saúde Coletiva, Rio de Janeiro, v. 15, n. 1, p. 39-40, 2010.

FAO/WHO. Basic texts on food hygiene. Roma: Codex Alimentarius Comission, 1997. HERNÁNDEZ, L. M. Brief diagnosis of the Chilean organic products sector. ProChile, 28 December 2000.

LUCENA, T. C. et al. Educação ambiental, sustentabilidade e saúde na criação de uma horta escolar: Melhorando a qualidade de vida e fortalecendo o conhecimento. Revista Brasileira de Educação e Saúde, Pombal, v. 5, n. 2, p. 01-09, 2015.

LUDKE, M. et al. 0 professor e a pesquisa. Campinas, SP: Papirus, 2001.

MACEDO, R. S. Currículo, campo, conceito e pesquisa. 6. ed. Petrópolis: Vozes, 2013. MACHADO, M. M. A educação de jovens e 
adultos após 20 anos da Lei n. 9.394 de 1996. Revista Retratos da Escola, Brasília, v. 10, n. 19, jul./dez. p. 429-451, 2016.

MANZUR, C. E. et al. Avaliação da prevalência de alimentos orgânicos e adesão à alimentação escolar de um Colégio em regime de internato de Guarapuava, Paraná. Revista UNINGÁ, Maringá, v. 15, n. 1, jul./set. p. 61-65, 2013.

MOTTA, M. B.; TEIXEIRA, F. M. Educação alimentar na escola por uma abordagem integradora nas aulas de ciências. Interação, Goiânia, v. 37, n. 2, jul./dez. p. 359379, 2012.

OLIVEIRA, I. G. Alimentação escolar no discurso de manipuladores de alimentos de escolas brasileiras. 89f. Dissertação (Mestrado em Nutrição e Saúde) - Universidade Federal de Goiás, Goiás, 2017.

ORMOND, J. G. P. et al. Agricultura orgânica: quando o passado é futuro. BNDES Setorial, Rio de Janeiro, n. 15, p. 3-34, 2002.

PAIVA, J. Educação de Jovens e Adultos: movimentos pela consolidação de direitos. In: Revista REVEJA, Belo Horizonte, v. 1, p. 68-84, 2007.

PRINCÍPIOS E DIRETRIZES DE UMA POLÍTICA DE SEGURANÇA ALIMENTAR E NUTRICIONAL. Textos de Referência da II Conferência Nacional de Segurança Alimentar e Nutricional. Brasília: Conselho Nacional de Segurança Alimentar e Nutricional: CONSEA, 2004.

PROJETO POLÍTICO PEDAGÓGICO. Escola Municipal Jorge Amado. Palmas: Prefeitura Municipal de Palmas / Secretaria da Educação e Cultura, 2017.

SANTOS, L. A. S. Food and nutrition education in the context of promoting healthy food practices. Revista de Nutrição, Campinas, v. 18, n. 5, p. 681-692, 2005.

SCIALABBA, N. E. Global Trends in Organic
Agriculture Markets and Countries' Demand for FAO Assistance. Roma: FAO, 2005.

SILVA, E. C. R. S. et al. Abordagens Pedagógicas em Educação Alimentar e Nutricional em Escolas no Brasil. In: Anais...VII National Meeting of Research in Education in Sciences. Florianópolis, 2009, p. 1-12.

SILVA, D. C. S. et al. Alimentação saudável na perspectiva do aluno de EJA em escola pública, Lucena - PB. In: Anais...XI Congresso Nacional de Educação (EDUCERE). Curitiba-PR, p. 27144-27152, 2013.

SANTOS, A. S.; AMORIM, A. O currículo e a educação de jovens e adultos: a perspective crítica em foco. Rev. Educ., Campinas, v. 1, n. 21, jan./abr. p. 117-126, 2016.

TRIVIÑOS, A. N. Introdução à pesquisa em ciências sociais: pesquisa qualitativa em educação. São Paulo: Atlas, 1987.

VEIGA, I. A. (Org.). Projeto Político Pedagógico da escola: uma construção possível. Campinas, SP: Papirus, 1995.

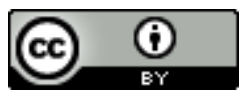

License information: This is an openaccess article distributed under the terms of the Creative Commons Attribution License, which permits unrestricted use, distribution, and reproduction in any medium, provided the original work is properly cited.

Artigo recebido em 31 de julho de 2017.

Avaliado em 09 de agosto de 2017.

Aceito em 15 de agosto de 2017.

Publicado em 22 de setembro de 2017.

\section{Como citar este artigo (ABNT):}

BARBOSA, Katiane Machado Gomes; ARAÚJO, Gustavo Cunha de; OLIVEIRA, Deyla Paula de. Exploration of the level of knowledge on organic and food security of adolescent, young and adult students of a public school in Palmas-TO. Estação Científica (UNIFAP), Macapá, v. 7, n. 2, p. 87-100, maio/ago. 2017. 